\title{
KAROLINA SZYDŁOWSKA
}

ORCID: 0000-0002-5448-160X

Katolicki Uniwersytet Lubelski Jana Pawła II

\section{GLOSA KRYTYCZNA DO UCHWAŁY SĄDU NAJWYŻSZEGO Z DNIA 23 LUTEGO 2018 ROKU, III CZP 88/17}

\begin{abstract}
Abstrakt: Niniejsza glosa stanowi próbę polemiki ze stanowiskiem Sądu Najwyższego wyrażonym w uchwale z dnia 23 lutego 2019 roku (III CZP 88/17). Autorka nie zgadza się z poglądem wyrażonym w uchwale, zakładającym, że przepis art. 79, ust. 1, pkt 1, lit. h ustawy z dnia 28 lipca 2005 roku o kosztach sądowych w sprawach cywilnych (tekst jedn.: Dz.U. z 2018 r. poz. 300) dotyczy wyłącznie ugody sądowej oraz ugody zawartej przed mediatorem. Autorka, konfrontując kategoryczną tezę uchwały z ogólnymi dyrektywami wykładni, opowiada się za szerokim rozumieniem terminu ,ugody” w rozumieniu powołanego przepisu i objęcie jego hipotezą również tak zwanych „ugód pozasądowych”.
\end{abstract}

Słowa kluczowe: ugoda, ugoda sądowa, ugoda zawarta przed mediatorem, zwrot opłaty sądowej

\section{WSTĘP}

Niniejsza glosa ukazuje problematykę wykładni art. 79, ust. 1, pkt, 1, lit. h ustawy z dnia 28 lipca 2005 roku o kosztach sądowych w sprawach cywilnych ${ }^{1}$, a ściślej tego, czy hipoteza powołanego przepisu obejmuje tak zwane ,ugody pozasądowe”. Teza uchwały przybiera kategoryczną formę, co jednak nie przekonuje autorki glosy. Biorąc pod uwagę aktualność tematu, jak również ważną dla każdego uczestnika postępowania sferę fiskalną, autorka podejmuje próbę skonfrontowania tezy zaprezentowanej przez Sąd Najwyższy z ogólnymi zasadami wykładni, a zwłaszcza z zasadą lege non distinguente nec nostrum est distinguere.

1 Ustawa z dnia 28 lipca 2005 roku o kosztach sądowych w sprawach cywilnych (tekst jedn. Dz.U. z 2020 r. poz. 755), dalej: u.k.s.c. 


\section{TEZA}

Użyty przez ustawodawcę w art. 79 ust. 1, pkt 1, lit. h u.k.s.c. termin „ugoda” obejmuje ugodę sądową, ugodę zawartą przed mediatorem, jak również ugodę pozasądową.

\section{STAN FAKTYCZNY}

W sprawie, na tle której zapadło głosowane orzeczenie, powód W. D. domagał się od pozwanego Towarzystwa Ubezpieczeń E. S.A. wypłacenia kwoty 2109,99 zł. Sąd I instancji wydał w postępowaniu upominawczym nakaz zapłaty, w którym w całości uwzględnił żądanie pozwu. Po wniesieniu sprzeciwu przez stronę pozwaną, strony zawarły ugodę pozasądową, skutkiem czego było cofnięcie pozwu przez powoda. Jednocześnie wystąpił on z żądaniem zwrotu uiszczonej opłaty od pozwu. Postanowieniem z 20 marca 2017 roku Sąd Rejonowy umorzył postępowanie i zwrócił powodowi jedynie połowę uiszczonej opłaty, zaś orzeczenie oparł na art. 79 ust. 1 pkt 3 u.k.s.c., argumentując, że cofnięcie pozwu nastąpiło co prawda przed rozpoczęciem posiedzenia wyznaczonego na rozprawę, jednak pozwanemu został już doręczony odpis pozwu. Zażalenie na takie rozstrzygnięcie wniósł powód, zaś Sąd Okręgowy, rozpoznając wniesiony środek odwoławczy, przedstawił do Sądu Najwyższego zagadnienie prawne sprowadzające się do pytania, czy hipoteza art. 79 ust. 1 pkt 1 lit. h u.k.s.c. obejmuje swym zakresem również zawarcie ugody pozasądowej.

\section{STANOWISKO SĄDU NAJWYŻSZEGO}

Sąd Najwyższy po rozstrzygnięciu przedstawionego zagadnienia prawnego doszedł do przekonania ujętego w tezie glosowanego orzeczenia. Na wstępie swoich rozważań Sąd Najwyższy zwrócił uwagę na liczne nowelizacje art. 79 u.k.s.c., który ze względu na swą funkcję fiskalną powinien być sformułowany bardziej precyzyjnie. Jednakże w ocenie Sądu Najwyższego ${ }^{2}$ mimo pojawiających się „niedociągnięć” legislacyjnych, pewne terminy winny być odczytywane przez pryzmat prawa procesowego. W takim duchu, jak zważył Sąd Najwyższy, należy interpretować termin „,ugoda”. Wobec tego, skoro art. 79 ust. 1 pkt 1 lit. h u.k.s.c. odwołuje się ogólnie do terminu ,ugody”, to należy poczytywać, że ustawodawca miał na myśli ugodę procesową, którą niewątpliwie jest ugoda zawarta przed sądem oraz ugoda zawarta przed mediatorem. Tym samym Sąd Najwyższy zdecydowanie wykluczył ugody pozasądowe $\mathrm{z}$ hipotezy powołanego przepisu jako

2 R. Haugen, Teoria nowoczesnego inwestowania, Warszawa 1996. 
znajdujące się poza obszarem zainteresowań prawa procesowego. Na poparcie sformułowanej tezy Sąd Najwyższy wskazał również na kontekst normatywny terminu „ugoda” zawartego w art. 79 ust. 1 pkt 1 lit. h u.k.s.c., który zestawiony został z ,zakończeniem postępowania”. Ponadto z uzasadnienia wynika, że jedynie w odniesieniu do ugody procesowej sąd ma możliwość dokonania pełnej kontroli, czy do zawarcia ugody doszło przed rozpoczęciem rozprawy. W konkluzji Sąd Najwyższy podkreślił, że przyjęcie odmiennego stanowiska i objęcie hipotezą art. 79 ust. 1 pkt 1 lit. h u.k.s.c. także ugód pozasądowych, prowadziłoby do licznych nadużyć procesowych i fingowania rzekomych ugód pozasądowych w celu wyłudzania uiszczonej opłaty. Na poparcie takiego poglądu został powołany judykat Sądu Najwyższego z dnia 21 kwietnia 1960 roku oraz uzasadnienie projektu ustawy z dnia 10 września 2015 roku $^{3}$.

\section{PRÓBA POLEMIKI Z TEZĄ ZAPREZENTOWANĄ PRZEZ SACD NAJWYŻSZY}

W ocenie autorki należałoby zaaprobować twierdzenie odmienne, aniżeli zawarte w tezie głosowanego orzeczenia, i objąć hipotezą art. 79 ust. 1 pkt 1 lit. h u.k.s.c. również ugody pozasądowe. Truizmem jest twierdzenie, że w obrocie prawnym funkcjonują ugody sądowe i pozasądowe, przy czym jedność systemu prawa nie uzasadnia traktowania ugody sądowej w oderwaniu od przepisów prawa cywilnego materialnego ${ }^{4}$. Ugoda pozasądowa nie posiada $\mathrm{w}$ języku prawniczym jednoznacznej konotacji. Swym zakresem obejmuje bowiem nie tylko ugodę normowaną art. 917 kodeksu cywilnego ${ }^{5}$, lecz również inne umowy prawa prywatnego o charakterze nowacyjnym w postaci pojednań, sojuszy i kompromisów grzecznościowych ${ }^{6}$. W orzecznictwie przyjmuje się, że ugoda pozasądowa to umowa wzajemna, konsensualna, obligacyjna i kauzalna, zaś jej istotą jest czynienie sobie wzajemnych ustępstw w zakresie stosunku prawnego między stronami ${ }^{7}$. Przyjmuje się, że ugoda pozasądowa może przybrać różną postać, jednak warunkiem sine qua non uznania danej czynności prawnej za ugodę są wzajemne ustępstwa

${ }^{3}$ Ustawa z dnia 10 września 2015 roku o zmianie niektórych ustaw w związku ze wspieraniem polubownych metod rozwiązywania sporów (Dz.U. z 2015 r. poz. 1595), dalej: ustawa nowelizująca.

4 Wyrok Sądu Najwyższego z dnia 1 lutego 2000 roku, I PKN 503/99, OSNP 2001, nr 12, poz. 411 .

5 Ustawa z dnia 23 kwietnia 1964 roku - Kodeks cywilny (tekst jedn. Dz.U. z 2019 r. poz. 1145), dalej: k.c.

${ }^{6}$ P. Feliga, [w:] Ustawa o kosztach sądowych $w$ sprawach cywilnych. Komentarz, red. P. Feliga, Warszawa 2019, s. 656.

7 Wyrok Sądu Apelacyjnego w Szczecinie z dnia 21 lutego 2013 roku, I ACa 794/12, LEX nr 1344212. Wyrok Sądu Apelacyjnego w Krakowie z dnia 24 stycznia 2019 roku, I ACa 225/18, LEX nr 2736579. 
obu stron ${ }^{8}$. Z kolei ugoda sądowa jest czynnością prawną o podwójnym charakterze: materialnoprawnym i procesowym, w związku z czym jej materialnoprawne skutki należy oceniać według prawa cywilnego materialnego, zaś procesowe według prawa postępowania cywilnego'.

Z powyższego wynika, że ugoda sądowa stanowi swoiste porozumienie co do istniejącego między stronami stosunku prawnego, zmierzające do wywołania skutków w dziedzinie prawa materialnego i w tym zakresie porozumienie to jest ugodą w rozumieniu art. 917 k.c. ${ }^{10}$. Podkreślenia wymaga, że ugoda sądowa, w odróżnieniu od ugody pozasądowej, zawiera w sobie dodatkowo dorozumiane oświadczenia procesowe stron zmierzające do likwidacji sporu in merito i umorzenia toczącego się postępowania. Autorka zdaje sobie sprawę, że problematyka ugód sądowych i pozasądowych jest bardzo obszerna, stąd rozważania w tej materii zostaną ograniczone do niezbędnego minimum. Dyskusyjny w niniejszej sprawie nie jest bowiem charakter zawartej przez strony ugody (co było w sprawie bezsporne), ale okoliczność zakresu normatywnego hipotezy art. 79 ust. 1 pkt 1 lit. h u.k.s.c.

Wątpliwości budzi przede wszystkim kategoryczny wniosek, że użyty w art. 79 ust. 1 pkt 1 lit. h u.k.s.c. termin ,ugoda”, bez dokładniejszego określenia, obejmuje wyłącznie ugodę sądową, a więc ugodę zawartą przed sądem i ugodę zawartą przed mediatorem. Taki pogląd jawi się jako sprzeczny z ogólną zasadą prawa lege non distinguente nec nostrum est distinguere, co w przekładzie na język polski oznacza, że brak rozróżnień w ustawie stanowi świadome i zamierzone działanie legislacyjne, wobec czego stosujący prawo winni je interpretować w tym właśnie duchu i unikać wprowadzania rozróżnień. Tymczasem Sąd Najwyższy, rozstrzygając przedstawione zagadnienie prawne, dokonał wspomnianego rozróżnienia, co - w ocenie autorki - było nieuzasadnione z poniższych przyczyn.

Punktem wyjścia do dalszych rozważań winna być dokładna analiza literalnego brzmienia art. 79 u.k.s.c. Już z pobieżnej lektury powołanego przepisu wynika, że ustawodawca posłużył się trzema różnymi zwrotami w kontekście zawartej przez strony ugody. W art. 79 ust. 1 pkt 1 lit. h jest mowa o ,postępowaniu, które zakończyło się zawarciem ugody”, art. 79 ust. 1 pkt 2 lit. a stanowi o „zawarciu ugody przed mediatorem", zaś w art. 79 ust. 1 pkt lit. d ustawodawca posłużył się terminem „sprawy, która zakończyła się zawarciem ugody sądowej”. Z powyższego wynika, że każdemu z tych trzech sformułowań ustawodawca przypisał określony kontekst znaczeniowy, w świetle którego należy dokonywać interpretacji użytych w przepisie zwrotów. Tym samym, skoro w stanowiącym przedmiot polemiki art. 79 ust. 1 pkt 1 lit. h u.k.s.c. ustawodawca użył ogólnego terminu ,ugody”,

8 T. Bielska-Sobkowicz, [w:] Kodeks cywilny. Komentarz, t. 4 i 5. Zobowiązania. Część szczegółowa, red. J. Gudowski, Warszawa 2017, s. 767.

9 Wyrok Sądu Najwyższego z 17 lipca 1984 roku, II CR 214/84, OSNCP 1985, nr 4, poz. 52.

10 Uchwała Sądu Najwyższego z dnia 20 grudnia 1969 roku, III PZP 43/69, OSNC 1970, nr 3 , poz. 40 . 
brak jakichkolwiek podstaw, by narzucać konkretne rozwiązanie interpretacyjne zakładające, że hipoteza powołanego przepisu nie obejmuje ugód pozasądowych. Biorąc pod uwagę fiskalny i restrykcyjny charakter unormowań ustawy o kosztach sądowych w sprawach cywilnych, konieczne jest stosowanie w pierwszej kolejności reguł wykładni językowej i semantycznej ${ }^{11}$. Oznacza to, że odstępstwa w kierunku innych typów wykładni wymagają ważnych powodów i szczególnej ostrożności ${ }^{12}$. Co więcej, nie przekonuje argumentacja, że za wąskim rozumieniem terminu ,ugody” na gruncie art. 79 ust. 1 pkt 1 lit. h u.k.s.c. przemawia jej powiązanie z ,zakończeniem postępowania”. Podkreślić należy, że przypadki cofnięcia pozwu po zawarciu przez strony ugody są w praktyce orzeczniczej bardzo częste. Jakkolwiek zgodzić należy się ze stwierdzeniem, że samo zawarcie ugody nie kończy postępowania między stronami, to jednak skuteczne cofnięcie pozwu wpływa bezpośrednio na przebieg postępowania, które kończy się jego umorzeniem na podstawie art. 355 k.p.c., podobnie jak zawarcie ugody.

Ponadto nie przekonuje przyjęcie a priori złej woli uczestników postępowania, którzy mieliby decydować się na zawieranie pozornych ugód pozasądowych w celu uzyskania zwrotu całej opłaty uiszczonej od pozwu. Stosownie do art. $126^{2}$ $\S 1$ k.p.c. ${ }^{13}$ sąd nie podejmie żadnej czynności na skutek pisma, od którego nie została uiszczona należna opłata. $Z$ kolei w myśl art. 3 ust. 1 u.k.s.c. pismo podlega opłacie, jeżeli przepis ustawy przewiduje jej pobranie. Regułą jest zatem odpłatność czynności sądowych, a nieuiszczenie należnej opłaty powoduje, że wniesione pismo nie wywołuje skutków prawnych związanych $\mathrm{z}$ jego wniesieniem (art. $130 \S 2$ k.p.c.). Pewne odstępstwo od powyższej zasady odpłatności stanowi art. 79 u.k.s.c., który przewiduje zwrot z urzędu opłaty uiszczonej od pisma, pomimo tego, że sąd podjął określone czynności w wyniku jego wniesienia ${ }^{14}$. Tym samym część czynności sądowych staje się wyłączona z obowiązku pokrycia przez stronę kosztów ich podjęcia ${ }^{15}$. Wskazuje się, że celem wspomnianej regulacji jest zachęcanie stron do ugodowego sfinalizowania sprawy poprzez wymienienie sytuacji dyspozytywnych prowadzących do usprawnienia postępowania sądowego, przy czym zwrot nie może być uzależniony od sytuacji materialnej strony ${ }^{16}$. Nie powinno budzić wątpliwości, że wystąpienie na drogę sądową z żądaniem rozstrzygnięcia sporu świadczy o silnym nasileniu konfliktu istniejącego między

11 P. Feliga, op.cit., s. 636.

12 P. Rylski, Ustawa o kosztach sadowych w sprawach cywilnych. Analiza funkcjonowaniawnioski de lege ferenda, Warszawa 2015, s. 53.

13 Ustawa z dnia 17 listopada 1964 roku - Kodeks postępowania cywilnego (tekst jedn. Dz.U. z 2020 r. poz. 1575), dalej: k.p.c.

14 P. Feliga, op. cit., s. 632-633.

15 M. Nowocień, [w:] Kodeks postępowania cywilnego. Komentarz do zmian 2019, t. 1 i 2. Koszty sadowe w sprawach cywilnych. Dochodzenie roszczeń w postepowaniu grupowym. Przepisy przejściowe, red. T. Zembrzuski, Warszawa 2020, s. 540.

16 A. Górski, [w:] Koszty sądowe w sprawach cywilnych. Ustawa i orzekanie. Komentarz praktyczny, red. A. Górski, L. Walentynowicz, Warszawa 2008, s. 90. 
stronami, często niereprezentowanymi przez profesjonalnych pełnomocników. W przypadku takich osób bardzo często będzie można zaobserwować swoisty brak świadomości, że ugodzenie się poza procesem nie przyniesie im żadnej korzyści finansowej, w szczególności w postaci zwrotu uiszczonej opłaty. Tym bardziej należałoby zatem ,premiować” zachowania świadczące o chęci ugodowego załatwienia sprawy, w tym zwłaszcza poprzez zawarcie ugody pozasądowej. Ciężko bowiem zakładać z góry złą wolę stron i ograniczać ich motywację do chęci wzbogacenia się. Powyższe przemawia także za szerokim rozumieniem pojęcia „ugody” na gruncie art. 79, ust. 1, pkt 1, lit. h u.k.s.c.

W tym miejscu zasadne wydaje się zwrócenie uwagi na art. 10 k.p.c., nakładający na sąd powinność dążenia w każdym stanie postępowania do ugodowego załatwiania spraw, w których dopuszczalne jest zawarcie ugody, wskazując jako jeden z preferowanych sposobów osiągnięcia tego celu nakłanianie stron do mediacji ${ }^{17}$. Należy zgodzić się z poglądem, że sposób ugodowego załatwienia sprawy nie ogranicza się do zawarcia ugody przed sądem albo przed mediatorem, a ugodowe załatwienie sprawy może nastąpić także w inny sposób. W konsekwencji sąd może wydać orzeczenie zgodne z treścią ugody zawartej przez strony poza posiedzeniem sądowym, w tym również zawartej przed wszczęciem procesu, z tym zastrzeżeniem, że jakkolwiek taka ugoda nie wiąże sądu, to jednak winna być ona uwzględniona przy rozstrzyganiu sprawy ${ }^{18}$. Strony mogą mieć bowiem interes w uzyskaniu orzeczenia o określonej treści, zgodnego z ich wolą, chociażby ten sam skutek mogłyby osiągnąć w drodze ugody. Motywów takiego zachowania można upatrywać w szczególnym przymiocie prawomocnego orzeczenia, jakim niewątpliwie jest powaga rzeczy osądzonej. Nie budzi bowiem wątpliwości, że atrybutu takiego nie posiada ugoda sądowa ${ }^{19}$.

Na koniec należy odnieść się również do celu ustawy nowelizującej z 10 września 2015 roku, której głównym zamierzeniem było spopularyzowanie polubownych metod załatwiania sporów, zwłaszcza mediacji w sprawach cywilnych ${ }^{20}$. Ustawa ta nieznacznie zmodyfikowała treść art. 10 k.p.c. przez podkreślenie, że sąd nie tylko powinien, ale ma dążyć do ugodowego załatwiania sprawy, w szczególności przez nakłanianie stron do mediacji. Autorka nie zgadza się z poglądem, że celem tej ustawy było szczególne premiowanie ugód sądowych oraz ugód zawieranych przed mediatorem. Taki wniosek bynajmniej nie wypływa z tytułu ustawy, ani też

17 J. Jagieła, [w]: Kodeks postępowania cywilnego, t. 1. Komentarz do art. 1-366, red. A. Marciniak, K. Piasecki, Warszawa 2016, s. 111.

18 Ibidem, s. 113.

19 Wyrok Sądu Najwyższego z dnia 9 maja 1997 roku, I PKN 143/97, OSNAPiUS 1998, nr 6, poz. 181 .

20 A. Jakubiak-Mirończuk, M. Stachura, [w:] Alternatywne i polubowne sposoby rozstrzygania sporów na gruncie przepisów Kodeksu postępowania cywilnego, Warszawa 2017, s. 23. 
z lektury uzasadnienia projektu nowelizacji. Istota i znaczenie pozasądowych metod rozwiązywania sporów wynika bowiem już z pierwszej strony uzasadnienia, na której wprost przyznaje się, że metody te stanowią zdecydowanie sprawniejszą — a przede wszystkim tańszą — alternatywę dla rozstrzygania spraw na drodze procesu cywilnego. Fakt, że ustawodawca w szczególnym stopniu skoncentrował się na mediacji, nie może degradować innych polubownych metod rozwiązywania sporów. Intencją ustawodawcy było raczej popularyzowanie każdej z ugód, aniżeli szczególne potraktowanie ugód sądowych i ugód zawieranych w toku postępowania mediacyjnego. Zdaniem autorki przyjęcie innego stanowiska skutkować będzie wypaczeniem celu ustawy nowelizującej i zaprzeczeniem racjonalności ustawodawcy w różnicowaniu poszczególnych terminów.

\title{
KONKLUZJA
}

W ocenie autorki Sąd Najwyższy w głosowanej uchwale nieprawidłowo dokonał interpretacji pojęcia „ugody”, o której mowa w art. 79 ust. 1 pkt 1 lit. h u.k.s.c. Skoro w powołanym przepisie ustawodawca wprost posłużył się ogólnym terminem ,ugody”, rezygnując z dookreślenia, o jakie ugody chodzi, to ogólne dyrektywy wykładni zakazują dokonywania rozróżnień w tym zakresie. Opowiedzenie się bowiem za poglądem wyrażonym w głosowanej uchwale jest sprzeczne z zasadami wykładni literalnej i funkcjonalnej, a nade wszystko godzi w chęć rozwiązywania sporu poprzez podjęcie dialogu.

\section{CRITICAL COMMENTARY OF THE SUPREME COURT'S RESOLUTION FROM 23RD OF FEBRUARY 2018 III CZP 88/17}

\author{
Summary
}

The present commentary portrays the topic of interpretation of art. 79(1)(1)(h) from the Act on Court Costs in Civil Cases, in specific if the hypothesis of the given article consists of "out-of-court settlements". Thesis of the resolution takes a categorical form, however it does not persuade the author of the commentary. Given the present nature of the topic as well as the fiscal theme of the issue, which is important to every participant of the civil proceeding, author attempts to confront the thesis resolved by the Supreme Court with general principles of interpretation, especially with the principle lege non distinguente nec nostrum est distinguere.

Keywords: settlement, court settlement, settlement made before a mediator, court fee refund 


\section{BIBLIOGRAFIA}

Kodeks cywilny. Komentarz, t. 4 i 5. Zobowiąania. Część szczegółowa, red. J. Gudowski, Warszawa 2017.

Kodeks postępowania cywilnego. Komentarz do zmian 2019, t. 1 i 2. Koszty sadowe w sprawach cywilnych. Dochodzenie roszczeń w postępowaniu grupowym. Przepisy przejściowe, red. T. Zembrzuski, Warszawa 2020.

Feliga P., Ustawa o kosztach sądowych w sprawach cywilnych. Komentarz, Warszawa 2019.

Górski A., Walentynowicz L., Koszty sądowe w sprawach cywilnych. Ustawa i orzekanie. Komentarz praktyczny, red. A. Górski, L. Walentynowicz, Warszawa 2008.

Jakubiak-Mirończuk A., Stachura M., Alternatywne i polubowne sposoby rozstrzygania sporów na gruncie przepisów Kodeksu postępowania cywilnego, Warszawa 2017.

Marciniak A., Piasecki K., Kodeks postepowania cywilnego, t. 1. Komentarz. Art. 1-366, Warszawa 2016.

Rylski P., Ustawa o kosztach sądowych w sprawach cywilnych. Analiza funkcjonowania - wnioski de lege ferenda, Warszawa 2015. 